\title{
Assessment of Soil Contamination through E-Waste Recycling Activities in Tema Community One
}

\author{
Richard Amfo-Otu ${ }^{1}$, John Kwesi Bentum ${ }^{2}$ \& Stephen Omari ${ }^{1}$ \\ 1 Environmental and Natural Resources Management Department, Presbyterian University College, \\ Akropong-Akuapem, Ghana \\ ${ }^{2}$ Department of Chemistry, University of Cape Coast, Cape Coast, Ghana \\ Correspondence: Richard Amfo-Otu, Environmental and Natural Resources Management Department, \\ Presbyterian University College, P.O. Box 393, Akropong-Akuapem, Ghana. Tel: 233-243-331-041. E-mail: \\ richard.amfo-otu@presbyuniversity.edu.gh
}

Received: January 22, 2013 Accepted: March 2, 2013 Online Published: March 19, 2013

doi:10.5539/ep.v2n2p66 URL: http://dx.doi.org/10.5539/ep.v2n2p66

\begin{abstract}
The study investigated the level of heavy metal concentration in soils at e-waste recycling sites at Tema Community One. Two soil samples were collected from six different sites for laboratory analysis with a seventh location serving as a control. Heavy metals in soil samples were analyzed by digestion method and the use of atomic absorption spectrophotometer. The concentrations of Cadmium, Copper and Mercury were all higher at all the sites than those obtained for the control. The site that recorded higher concentration for copper was about 1200 times higher than the value for the control but statistically, there was significant difference between the concentrations of copper from the six sites $(t=5.168, p=0.0036)$. Site 12 and Grand Mollen de Ghana site had concentrations which is 5 times higher than the control and there was significant difference between the concentrations from the six sites and the control $(\mathrm{t}=10.39, \mathrm{p}=0.0001)$ for the cadmium. The mean concentration of mercury from site 12 was found to be 34 times higher than the control value, however, there was no significant difference between the concentrations from the six e-waste recovery sites and the control $(\mathrm{t}=$ 2.593, $\mathrm{p}=0.05194)$. E-waste recycling has contributed to the heavy metal contamination of the soil at the recovery sites. Workers safety in relation to these heavy metals is therefore worth researching in the future.
\end{abstract}

Keywords: e-waste, recycling, heavy metals, contamination, soil

\section{Introduction}

Waste generation has increased drastically throughout the world and developing countries are not exempted due to high population growth, consumption of packaged products and adoption of Western life style through globalization and modernization. E-waste comprising electrical and electronic equipment (WEEE) and the quantities in waste generated by developing countries are gradually increasing (European Union, 2003a). The United Nations estimated that 20 to 50 million tons of e-waste are generated globally each year and Africa has been identified as one of the popular dumping grounds for old e-waste from the Western world (Koranteng \& Darko, 2011). Ghana is not exempted from the problem of e-waste. In 2008, it was estimated that about 16,000 tons of e-waste was imported into the country (Koranteng \& Darko, 2011).

The material constituent of e-waste in the waste stream has various substances which may be classified as hazardous and non-hazardous. According to Babu et al. (2007), about 66\% of e-waste by weight consists of metals such as iron, copper, aluminium and gold and nonferrous metals such as copper, aluminium and other precious metals constitute about $13 \%$ by weight. They further noted that e-waste could contain more than 1000 different substances including lead $(\mathrm{Pb})$, cadmium $(\mathrm{Cd})$, mercury $(\mathrm{Hg})$ and hexavalent chromium $(\mathrm{Cr})$ which are mostly toxic (Babu et al., 2007; Gaulon et al., 2005). Also it has been estimated that 21\% by weight of e-waste represent plastic materials in Europe (Wilkinson et al., 2001; ETC/RWM, 2003). Glass component forms about $5.4 \%$ of the total weight of waste from electric and electronic equipment every year in Europe (Theisen, 2002).

In this study, e-waste recycling means breaking down obsolete electronic materials to recover valuable materials which can be reused in another device or processed into a new product. This can actually help recover reusable components and base materials, such as $\mathrm{Cu}$ and other precious metals. However, inadequate facilities, high 
labour costs, and stringent environmental regulations have contributed to advanced countries not motivated to recycle e-waste but land filling, or exporting them to developing countries which is against the objectives of the Basel Convention (UNEP, 2009). In developing countries, primitive techniques are used in recycling, which may affect workers safety, public health and the environmental (Cobbing, 2008).

Studies have shown that e-waste can leach polychlorinated biphenyl's (PCBs) which are bioaccumulative in organisms and can lead to biomagnifications through the food chains and cause endocrine disruption (Deng et al., 2007). Heavy metals found in e-waste such as $\mathrm{Cd}, \mathrm{Hg}$ and $\mathrm{Cu}$ are known to be persistent in the environment, accumulative in plants, animals, humans and the environment. Exposure to these metals and their compounds are known to cause problems to the nervous system and genitourinary system (CDPHE, 2008; Tangahu et al., 2011; ATSDR, 1999; WHO, 1992). Land filling of obsolete refrigerators, freezers and air conditioning units containing ozone-depleting gases such as chlorofluorocarbons (CFCs) can release the gases which can have adverse environmental effects (Scheutz et al., 2004). Studies conducted on sediments taken from certain rivers in Guiyu, China were contaminated with high levels of $\mathrm{Cd}, \mathrm{Cu}, \mathrm{Ni}, \mathrm{Pb}$, and $\mathrm{Zn}$ (Wong et al., 2007; Herat, 2009).

E-waste generation rate is estimated to be less than $1 \%$ of municipal waste generated in Accra (WMD of AMA, 2010). In Ghana, there are many centres for recovery of valuable materials from e-waste but the main centre for this recovery activity within the country is the Agbogbloshie Scrap Market in Accra. Studies have been done on soil contamination through e-waste recovery at Agbogbloshie and Koforidua (Brigden et al., 2008). The present study sought to assess the potential of e-waste recycling activities to contribute to heavy metals contamination of the soils in Tema, Ghana.

\section{Methodology}

\subsection{Description of Study Area}

Tema as the industrial hub of the country is the third urbanized city in Ghana after Accra and Kumasi, hosting the country's biggest harbour. Geographically, it is located on $\left(5^{\circ} 37^{\prime} 0^{\prime \prime} \mathrm{N}, 0^{\circ} 10^{\prime} 0^{\prime \prime} \mathrm{W}\right)$. The city is bounded to the North-East by Kpong Katamanso District Assembly, to the South-West by Ledzokuku-Krowor Municipality, to the North-West by Ashaiman Municipality and to the south by Gulf of Guinea. It has an estimated population of 402,637 with males and females forming $48 \%$ and 52\% respectively (Ghana Statistical Service, 2012). E-waste scraps dealers activities are doted around the city especially in Community One which is located in Tema West.

\subsection{Soil Sampling and Preparation}

Soil samples were taken from e-waste recovery sites at Tema Community One. In all, a total of 12 composite soil samples were taken from six e-waste recycling sites to provide duplicate samples and two were taken from the same community but outside the e-waste recycling sites. The soils were taken at a depth of $30 \mathrm{~cm}$ from the surface of the ground using augur and kept in polyethylene bags in ice pack, sealed, labeled and transported to the Soil Research Institute (CSIR) laboratory for analysis. The soil samples were emptied into trays labeled according to the sample sites. The soil sample were freed from foreign objects (roots, pebbles, etc.) and later air dried. The samples were crushed, ground and homogenized using a porcelain pestle and mortar and were then passed through $2.0 \mathrm{~mm}$ sieve pore to constitute the actual workable samples. The workable soil samples were then placed into their respective labeled polyethylene bags and stored at room temperature, for the next phase of the analytical process.

\subsection{Laboratory Analysis}

The total $\mathrm{Cd}$ and $\mathrm{Hg}$ and $\mathrm{Zn}$ concentrations were determined using the US-EPA method 3050 of digestion of soil for metal content. A $0.5 \mathrm{~g}$ portion of soil was weighed into a beaker followed by addition of $10.0 \mathrm{ml}$ of $1: 1 \mathrm{HNO}_{3}$ : $\mathrm{H}_{2} \mathrm{O}$ to form a solution. The solution was heated to $95^{\circ} \mathrm{C}$ for $5 \mathrm{~min}$, followed by sequential addition of $5.0 \mathrm{ml}$ of concentrated $\mathrm{HNO}_{3}, 1.0 \mathrm{ml}$ of $30 \% \mathrm{H}_{2} \mathrm{O}_{2}$, and $5.0 \mathrm{ml}$ of concentrated $\mathrm{HCl}$. The resulting solution was filtered and diluted with deionised water to a final volume of $50.0 \mathrm{ml}$. The filtrate was kept in spinning tubes for analysis using Atomic Absorption Spectrophotometer (Fan et al., 2011).

\subsection{Data Analysis}

Data from the laboratory results were tested for significant difference using computer application software called Palaeonotological Statistical Tool (PAST), at 95\% confidence level for one tailed t-test. The means were generated from the spread sheet 2007 version of Microsoft. 


\section{Results and Discussion}

Table 1. Mean concentrations of heavy metals from e-waste recycling sites in Tema Community 1

\begin{tabular}{lllllllll}
\hline $\begin{array}{l}\text { Heavy Metal } \\
\text { /Location }\end{array}$ & GMG & Site 20 & Site 2 & Site 12 & $\begin{array}{l}\text { Harbour } \\
\text { Area 1 }\end{array}$ & $\begin{array}{l}\text { Harbour } \\
\text { Area 2 }\end{array}$ & $\begin{array}{l}\text { Control } \\
\text { Instrument } \\
\text { Detection } \\
\text { Limit }\end{array}$ \\
\hline Copper $(\mathrm{mg} / \mathrm{kg})$ & 7834.92 & 1688.11 & 5686.72 & 5047.06 & 4003.46 & 3006.92 & 6.50 & 0.003 \\
Cadmium $(\mathrm{mg} / \mathrm{kg})$ & 2.60 & 1.80 & 2.40 & 1.60 & 1.95 & 1.40 & 0.50 & 0.002 \\
Mercury (mg/kg) & 0.94 & 0.12 & 0.50 & 1.30 & 0.13 & 0.11 & 0.04 & 0.001 \\
\hline
\end{tabular}

Source: Field soil sample analysis Data, 2012 at Soil Research Institute-Accra.

Table 2. Mean ratios of metal levels in the soils at the sites in relation to the sampled control

\begin{tabular}{ccccccc}
\hline Heavy Metals/E-waste Recovery Site & GMG & Site 20 & Site 2 & Site 12 & Harbour Area 1 & Harbour Area 2 \\
\hline Copper & 1200 & 259 & 871 & 773 & 613 & 460 \\
Cadmium & 5 & 4 & 5 & 3 & 4 & 3 \\
Mercury & 25 & 3 & 13 & 34 & 3 & 3 \\
\hline
\end{tabular}

Table 1 above revealed that the concentrations of $\mathrm{Cu}, \mathrm{Cd}$, and $\mathrm{Hg}$ were very high as compared to the control taken from the same vicinity where there was no e-waste recycling activity going on.

\subsection{Copper}

It was found out that GMG site had the highest $\mathrm{Cu}$ concentrations followed by Site 2 and Site 12. Thus, the mean concentration of $\mathrm{Cu}$ at the GMG site was about 259-1,200 times higher than that of the control as shown in table 2. Statistically, there was a significant difference between the concentrations from the six sites $(t=5.168, p=$ 0.0036). This implies that recovery of valuables from e-waste using the crude methods can contribute copper to the soil in high levels leading to contamination. These values are high compared with similar studies conducted at Agbogbloshie $(9,730 \mathrm{mg} / \mathrm{kg}$ ) and Koforidua $(14,300 \mathrm{mg} / \mathrm{kg}$ ) in Ghana (Brigden et al., 2008). Even though $\mathrm{Cu}$ is one of the valuable materials from e-waste, it is also known to serve as a catalyst for dioxin formation if the recycling activities are done using crude methods like open burning (Cui \& Zhang, 2008). Copper can affect water bodies, soil fertility, reduce microbial activities and crop production (Fan et al., 2011). It has been established that chronic exposure to $\mathrm{Cu}$ can lead to liver and kidney disorders with vomiting and abdominal pains as the symptoms (New Hampshire Department of Environmental Services, 2005). Exposure to high levels of $\mathrm{Cu}$ through inhalation is known to cause irritation of nose and throat, ingesting can cause nausea, vomiting, diarrhea, damage to the liver and kidneys, and can even cause death under extremely high ingestion (CDPHE, 2008).

\subsection{Cadmium}

Cadmium was the lowest in concentration after mercury at all the sites with the highest concentration occurring at GMG Site, followed by Site 2 and Harbour Area 1 respectively as indicated in Table 1 . Thus, the mean concentration of $\mathrm{Cd}$ was about 3-5 times higher than that of the control. These values however were very low compared to values obtained for $\mathrm{Cd}$ from other extraction or recycling sites at Agbogbloshie $(10 \mathrm{mg} / \mathrm{kg})$ and Koforidua ( $3 \mathrm{mg} / \mathrm{kg}$ ) sites (Brigden et al., 2008). This means that the recycling activities could contribute to the contamination of the soil which could pose life risk to the recyclers or value pickers working at these sites. Normally cadmium levels below $2 \mathrm{mg} / \mathrm{kg}$ in soils and sediments are taken to be acceptable (Brigden et al., 2008; Alloway, 1990; Salomons \& Forstner, 1984). In this study, GMG Site and Site 12 had a mean value of $2.6 \mathrm{mg} / \mathrm{kg}$ and $2.4 \mathrm{mg} / \mathrm{kg}$ respectively and were higher than the control values and can be said to be contaminated. Statistically, there was a significant difference between the concentrations from the six sites $(t=10.39, p=$ 0.0001). Cadmium is known to affect the kidney and its compounds are known to cause lung cancer in humans through inhalation (DHHS, 2005). Therefore the workers at these site and inhabitants in the area may be at risk of contract some of these diseases once exposed to the metal. 


\subsection{Mercury}

Mercury which causes a lot of hazards in environmental media and in humans was also detected at the e-waste recovery sites. The mean concentration of $\mathrm{Hg}$ from the Site 12 was found to be the highest, followed by GMG and site 2 respectively. Thus, $\mathrm{Hg}$ mean concentration was found to be about 3-34 times higher than that of the control. These values indicated that the e-waste recovery sites were contaminated with mercury and this could affect the health of workers at these sites and neighboring households who may be exposed to it. Statistically, there was no significant difference between the concentrations from all the six e-waste recovery sites $(\mathrm{t}=2.593$, $\mathrm{p}=0.05194)$. Mercury and its compounds are known to be toxic and accumulative, causing neurological and renal disturbances in humans (Tangahu et al., 2011). Mercury as a metal is known to affect the genitourinary system, the central and peripheral nervous systems as well as foetus. Inorganic mercury can leach or wash by runoffs into water bodies and can be transformed into methylated mercury, which bioaccumulates in living organisms and concentrates through the food chain, especially by fish (Pinto, 2008). Even though mercury concentrations were not significant in the soils, it could accumulate in the environment and pose serious risk to organisms and humans within the Community One environment.

\section{Conclusion}

The result of the study showed that $\mathrm{Cd}$ and $\mathrm{Cu}$ were present in the soils where e-waste recycling activities were carried out at appreciable levels whilst $\mathrm{Hg}$ was not significant. Thus, e-waste recycling activities at these sites were contributing to heavy metals pollution to the soil. The concentrations of the $\mathrm{Cd}, \mathrm{Hg}$, and $\mathrm{Cu}$ determined were in excess compared to the concentrations of the same metals in the control. Therefore the hypothesis that the concentrations of $\mathrm{Cd}$ and $\mathrm{Cu}$ in soils at e-waste recovery sites were higher than the soil without recycling activities was accepted and was rejected for $\mathrm{Hg}$. It is therefore important to investigate for the presences of other heavy metals, substituted organic compounds and their health implications on the scrap dealers at the sites.

\section{Acknowledgements}

The role of Presbyterian University College (PUC), Ghana, in sponsoring this study is well acknowledged. The contributions of Norgah Rachia and Gifty Adda in the data collection and laboratory analysis of the samples is appreciated. Much appreciation goes to Dr. Frank S. Arku and Mr. Edward Wiafe proof reading and Stella Buadi for editing the manuscript.

\section{References}

Alloway, B. J. (1990). Heavy Metals in Soils. New York: John Wiley and Sons, Inc.

ATSDR. (1999). Toxicological Profile for Cadmium. United States Public Health Service, Agency for Toxic Substances and Disease Registry, July 1999.

Babu, B. R., Parande, A. K., \& Basha, C. A. (2007). Electrical and electronic waste: a global environmental problem. Waste Management Research, 25, 307-318. http://dx.doi.org/10.1177/0734242X07076941

Brigden, K., Labunska, I., Santillo, D., \& Johnston, P. (2008). Chemical contamination at e-waste recycling and disposal sites in Accra and Korforidua, Ghana. Greenpeace research laboratories technical note. Retrieved from www.greenpeace.org

Cobbing, M. (2008). Toxic Tech: Not in Our Backyard. Uncovering the Hidden Flows of e-waste. Report from Greenpeace International. Retrieved from http://www.greenpeace.org/raw/content/belgium/fr/press/reports/toxic-tech.pdf

Colombia Department of Public Health and Environment (CDPHE). (2008). Fact Sheet: Evaluation of Onsite Surface Soil Exposures by Recreational Users at Standard Mine-Gunnison County, Colorado. The Colorado Cooperative Program for Environmental Health Assessments (CCPEHA), Colombia.

Cui, J. R., \& Zhang, L. F. (2008). Metallurgical recovery of metals from electronic waste: a review. J. Hazard Mater, 158, 228-256. http://dx.doi.org/10.1016/j.jhazmat.2008.02.001

Deng, W. J., Zheng, J. S., Bi, X. H., Fu, J. M., \& Wong, M. H. (2007). Distribution of PBDEs in air particles from an electronic waste recycling site compared with Guangzhou and Hong Kong, South China. Environ. Int., 33, 1063-9. http://dx.doi.org/10.1016/j.envint.2007.06.007

DHHS. (2005). 11th Report on Carcinogens. U.S. Department of Health and Human Services, US Public Health Service, National Toxicology Program.

European Topic Centre on Resource and Waste Management (ETC/RWM; Topic Centre of the European Environment Agency). (2003). Part of the European Environment Information and Observation Network 
(EIONET). Retrieved from http://www.waste.eionet.eu.int/waste/6

European Union. (2003a). Directive 2002/96/EC of the European Parliament and of the Council of 27 January 2003 on waste electrical and electronic equipment (WEEE). Official Journal of the European Union. Retrieved from http://www.europa.eu.int/eurlex/pri/en/oj/dat/2003/1_037/1_03720030213en00240038.pdf

Fan, J., He, Z., Ma, L. Q., \& Stoffella, P. J. (2011). Accumulation and availability of copper in citrus grove soils as affected by fungicide application. J. Soils Sediments, 11, 639-648. http://dx.doi.org/10.1007/s11368-011-0349-0

Gaulon, B., Rozema, L., \& Klomp, K. (2005). E-waste. Frank Mohr Institute. Retrieved from www.mohr-i.nl/mawiki/E_2dwaste_99

Ghana Statistical Serveice. (2012). 2010 population and housing census summary report of final results. Accra, Ghana: Sakoa Press Limited.

Herat, S. (2009). Review Sustainable Management of Electronic Waste. Clean, 35(4), 305-310.

Koranteng, S. S., \& Darko, D. A. (2011). E-Waste Menace in Ghana: Information Note. Institute of Environment and Sanitation. University of Ghana.

New Hampshire Department of Environmental Services, ARD-EHP-9. (2005). Copper: Health Information Summary, Environmental Fact Sheet. Retrieved from http://des.nh.gov/organization/commissioner/pip/factsheets/ard/documents/ard-ehp-9.pdf

Pinto, V. N. (2008). E-waste hazard. Indian Journal of Occupational and Environmental Medicine, 12(2), 65-70. http://dx.doi.org/10.4103/0019-5278.43263

Salomons, W., \& Forstner, U. (1984). Metals in the hydrocycle. Berlin, Heidelberg, New York, Tokyo: Springer-Verlag. http://dx.doi.org/10.1007/978-3-642-69325-0

Scheutz, C., Mosbaek, H., \& Kjeldsen, P. (2004). Attenuation of methane and volatile organic compounds in landfill soil covers. J. Environ. Qual., 33, 61-71. http://dx.doi.org/10.2134/jeq2004.0061

Tangahu, B. V., Abdullah, S. R. S., Basri, H., Idris, M., Anuar, N., \& Mukhlisin, M. (2011). A Review on Heavy Metals (As, $\mathrm{Pb}$, and $\mathrm{Hg}$ ) Uptake by Plants through Phytoremediation. International Journal of Chemical Engineering, 2011, 31. http://dx.doi.org/10.1155/2011/939161

Theisen, H. (2002). Collection of solid waste. In G. Tchobanoglous, \& F. Kreith (Eds.), Handbook of Solid Waste Management (2nd ed.). New York: McGraw-Hill.

UNEP. (2009). Basel Convention on the Control of Transboundary Movements of Hazardous Wastes and Their Disposal. United Nations Environment Programme. Retrieved from http://www.basel.int

Waste Management Department of Accra Metropolitan Assembly. (2010). Annual report of waste management department (unpublished).

Wilkinson, S., Duffy, N., Crowe, M., \& Nolan, K. (2001). Waste from Electrical \& Electronic Equipment. Environmental Protection Agency, Ireland.

Wong, C. S. C., Wu, S. C., Duzgoren-Aydin, N. S., Aydin, A., \& Wong, M. H. (2007). Trace Metal Contamination of Sediments in an E-Waste Processing Village in China. Environ. Pollut., 145, 434. http://dx.doi.org/10.1016/j.envpol.2006.05.017

World Health Organisation (WHO). (1992). Cadmium. Environmental Health Criteria 135. 